\title{
Leiomyoma in Retzius' space: An unusual location
}

\author{
Naoya Niwa, MD; Hitoshi Yanaihara, MD; Minoru Horinaga, MD; Hirotaka Asakura, MD
}

Department of Urology, Saitama Medical University, Japan

Cite as: Can Urol Assoc J 2013;7(9-10):e612-3. http://dx.doi.org/10.5489/cuaj.349

Published online September 10, 2013.

\section{Abstract}

We report the case of a 54-year-old woman who presented to our hospital with microscopic hematuria. An imaging study revealed a tumour in the Retzius' space. The tumour was surgically removed by an abdominal approach. Pathological examination revealed a leiomyoma. This case demonstrates a leiomyoma in an unusual location.

\section{Case report}

A 54-year-old female patient (gravida 2, para 0-0-2-0) was referred to our department after microscopic hematuria was detected during a health screening. Transvaginal ultrasonography revealed a $50 \times 18-\mathrm{mm}$ mass anterior to the bladder, and transabdominal ultrasonography showed a $95 \times 51-\mathrm{mm}$ mass between the bladder and the abdominal wall. Similarly, magnetic resonance imaging (MRI) scan revealed a $94 \times 53 \times 74-\mathrm{mm}$ smooth mass. On the T1-weighted image, the tumour showed homogeneous signal intensity equal to that of muscle; on the T2-weighted image, it had heterogeneous, low signal intensity with crack-like high-intensity lesions (Fig. 1, part A). Gadolinium-enhanced T1-weighted image revealed that the tumour was surrounded by an enhanced uniform thick capsule (Fig. 1, part B). There was no evidence that this tumour was directly connected to the surrounding structures, such as the bladder and ovaries. On the basis of the results of these imaging studies, a leiomyoma was suspected. The tumour was surgically removed, through the abdominal approach, to exclude malignancy. Because the encapsulated tumour had no direct connection to the surrounding structures and had no feeding vessels, it could be removed in its entirety.
On gross examination, the tumour was well circumscribed, encapsulated with thin fibrous tissue, and had a greatest diameter of $90 \mathrm{~mm}$. The cut surface of the tumour was solid and homogeneous (Fig. 1, part C). Pathologic examination revealed typical features of benign leiomyoma, consisting of spindle-shaped uniform cells without nuclear atypia and necrosis (Fig. 1, part D). Immunohistochemical study revealed that the tumour cells were positive for HHF35 and estrogen receptor.

The recovery period was uneventful, and there was no recurrence 2 years after surgery.

\section{Discussion}

Leiomyomas are common benign mesenchymal tumors that can originate from smooth muscle cells; however, leiomyomas in the retroperitoneal space are relatively rare. Only $15 \%$ to $20 \%$ of all retroperitoneal tumors are benign lesions, fewer than half are sarcomas, and the remainder consist of primary lymphoma or other malignancies besides sarcoma. ${ }^{1}$ The incidence of leiomyoma among all retroperitoneal tumours is estimated to be only $1.2 \%{ }^{2}$ Retroperitoneal leiomyoma are found most frequently in the pelvic retroperitoneum and in the posterior retroperitoneal space than in the anterior retroperitoneal space, including Retzius' space. ${ }^{3}$ Leiomyomas in Retzius' space are extremely rare, and only 3 cases have been reported (Table 1)., ${ }^{4,5}$

The differential diagnosis of tumours in Retzius' space includes true tumours and tumour-like lesions, such as a hematoma ${ }^{6}$ or an abscess. ${ }^{7}$ Although the most important differential diagnosis of retroperitoneal leiomyoma includes leiomyosarcoma, there are no reports of leiomyosarcoma in Retzius' space. True tumours in Retzius' space are extremely rare, and very few cases, including 3 cases of leiomyoma, have been reported. . $^{4,58-10}$

A clinical challenge in the management of retroperitoneal leiomyoma is the accuracy with which it can be dif- 


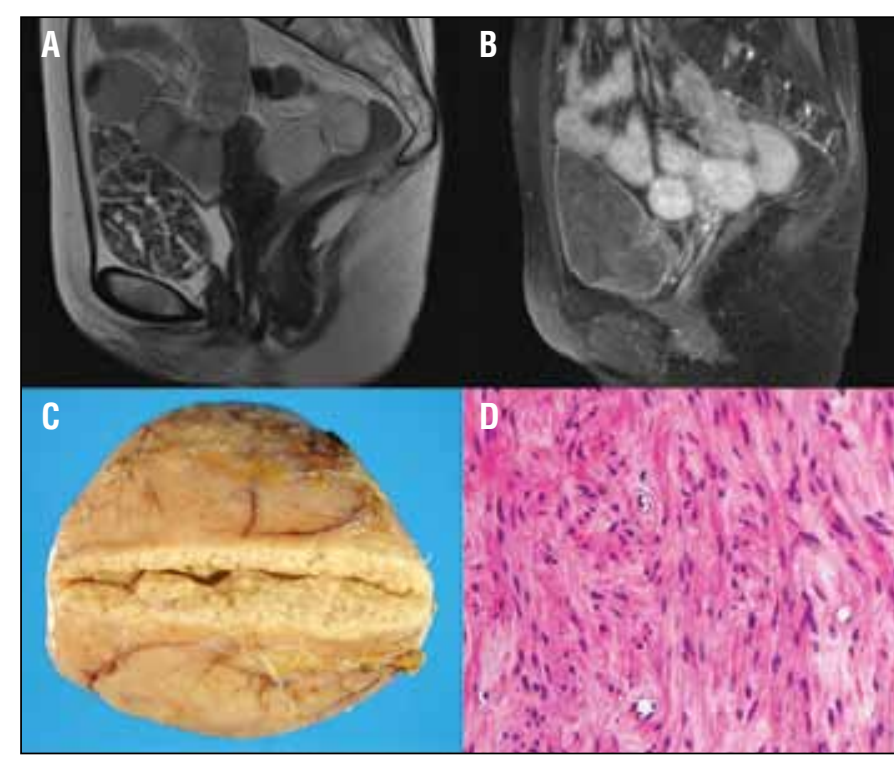

Fig. 1. (A) Magnetic resonance T2-weighted image showing a tumour with low signal intensity and crack-like high-intensity lesions. (B) Gadolinium-enhanced T1-weighted image revealing a tumor with signal intensity equal to that of muscle and surrounded by an enhanced uniform thick capsule. (C) The excised tumour encapsulated with thin fibrous tissue showed a solid and homogenous cut surface. (D) Hematoxylin and eosin-stained section $(\times 400)$. The tumour consists of spindle-shaped uniform cells without nuclear atypia or necrosis.

ferentiated from malignant tumours, such as leiomyosarcoma. Unfortunately, there is no highly accurate diagnostic modality to rule out malignancy. One study reported that pelvic MRI had $100 \%$ accuracy in differentiating uterine leiomyoma from uterine leiomyosarcoma. ${ }^{11}$ However, the number of cases (45 cases; 41 benign and 4 malignant) identified in the study was very small, and the ratio of benign to malignant lesions in uterine smooth muscle cell tumours was different from that in retroperitoneal smooth muscle cell tumours; hence, we could not apply the results to the diagnosis of retroperitoneal tumors (especially leiomyoma and leiomyosarcoma). Although image-guided percutaneous biopsies may be helpful in obtaining accurate pathological diagnosis before surgical interventions, they could expose patients to malignant cells if the pathology is not benign.

\section{Conclusion}

Treatment usually should be excision of the tumour. It is curative in most cases and is considered necessary to rule out malignancy given the current limitations in presurgical radiologic diagnosis. There is no report of medical

\begin{tabular}{|c|c|c|c|c|}
\hline Authors & Sex & $\begin{array}{l}\text { Age, } \\
\text { years }\end{array}$ & $\begin{array}{c}\text { Chief } \\
\text { complaint }\end{array}$ & $\begin{array}{c}\text { Turmour size } \\
\text { (modality) }\end{array}$ \\
\hline \multirow[t]{2}{*}{$\begin{array}{l}\text { Stutterecker } \\
\text { et al. }{ }^{1}\end{array}$} & $\mathrm{~F}$ & 56 & $\begin{array}{l}\text { Voiding } \\
\text { difficulty }\end{array}$ & 5-cm mass (MRI) \\
\hline & $\mathrm{F}$ & 55 & - & 2-cm mass (US) \\
\hline $\begin{array}{l}\text { Reisenauer } \\
\text { et al. }{ }^{2}\end{array}$ & $\mathrm{~F}$ & 54 & $\begin{array}{l}\text { Voiding } \\
\text { difficulty }\end{array}$ & $\begin{array}{l}4 \mathrm{~cm} \text { in its } \\
\text { greatest diameter }\end{array}$ \\
\hline $\begin{array}{l}\text { Niwa et al. } \\
\text { (current case) }\end{array}$ & $\mathrm{F}$ & 54 & $\begin{array}{l}\text { Microscopic } \\
\text { hematuria }\end{array}$ & $\begin{array}{c}9.4 \times 5.3 \times 7.4 \mathrm{~cm} \\
(\mathrm{MRI})\end{array}$ \\
\hline
\end{tabular}

F: female; US: ultrasonography; MRI: magnetic resonance imaging.

management or other interventional therapies, such as embolotherapy for retroperitoneal leiomyoma.

Competing interests: None declared.

This paper has been peer-reviewed.

\section{References}

1. Jemal A, Thomas A, Murray T, et al. Cancer statistics, 2002. CA Cancer J Clin 2002;52:23-47. http:// dx.doi.org/10.3322/caniclin.52.1.23

2. Albert PS, Sinatra T, Nagamatsu GR. Retroperitoneal leiomyoma presenting as prostatic mass. Urology 1974;3:607-9. http://dx.doi.org/10.1016/S0090-4295(74)80257-8

3. Poliquin V, Victory R, Vilos GA. Epidemiology, presentation, and management of retroperitoneal leiomyomata: systematic literature review and case report. J Minim Invasive Gynecol 2008;15:152-60. http:// dx.doi.org/10.1016/i.jmig.2007.12.009

4. Stutterecker D, Umek W, Tunn R, et al. Leiomyoma in the space of Retzius: a report of 2 cases. Am J Obstet Gynecol 2001;185:248-9. hittp://dx.doi.org/10.1067/mob.2001.114503

5. Reisenauer C, Walz-Mattmueller R, Solomayer EF, et al. Leiomyoma in the Retzius space: a rare cause for voiding difficulties. Int Urogynecol J Pelvic Floor Dysfunct 2007;18:1229-31. http://dx.doi. org/10.1007/s00192-007-0337-5

6. Dupas B, Barrier J, Michel P, et al. Diagnosis of hematomas in the Retzius space during anticoagulant therapy. Prospective study (11 cases) [in French]. Sem Hop 1983;59:3115-9.

7. Borten M, Friedman EA. Spontaneous prevesical (Retzius-space) abscess with extraperitoneal presacral dissemination. A case report. J Reprod Med 1984;29:841-4.

8. Payne $S$, Adair R, Alvarez J, et al. Aggressive angiomyxoma of the space of retzius: a case report. J Low Genit Tract Dis 2003;7:304-6. http://dx.doi.org/10.1097/00128360-200310000-00014

9. Okuda H. Spindle cell lipoma in Retzius' space. Int J Urol 2009;16:218-9. http://dx.doi.org/10.1111/ j.1442-2042.2008.02204.x

10. Kosumi T, Kubota A, Yonekura T, et al. Cystic lymphangioma of Retzius space manifested as acute abdomen. Eur J Pediatr Surg 2006;16:120-2. http://dx.doi.org/10.1055/s-2006-923999

11. Schwartz $L B$, Zawin $M$, Carcangiu $M L$, et al. Does pelvic magnetic resonance imaging differentiate among the histologic subtypes of uterine leiomyomata? Fertil Steril 1998;70:580-7. http://dx.doi. org/10.1016/50015-0282(98)00193-9

Correspondence: Dr. Naoya Niwa, Department of Urology, Saitama Medical University, Japan; ashandjesus@gmail.com 